\title{
Research Data Management (RDM) Strategy for Academic Libraries in Ghana: Setting a National Development Agenda
}

\author{
Isidore Komla Zotoo, Guifeng Liu \\ Institute of Science and Technology Information, Jiangsu University, Zhenjiang, China \\ Email: zotook@yahoo.com, liugu ifeng29@163.com
}

How to cite this paper: Zotoo, I.K. and Liu, G.F. (2019) Research Data Management (RDM) Strategy for Academic Libraries in Ghana: Setting a National Development Agenda. Open Access Library Journal, 6: e5383.

https://doi.org/10.4236/oalib.1105383

Received: April 10, 2019

Accepted: April 26, 2019

Published: April 29, 2019

Copyright $\odot 2019$ by author(s) and Open Access Library Inc.

This work is licensed under the Creative Commons Attribution International License (CC BY 4.0). http://creativecommons.org/licenses/by/4.0/

\section{Open Access}

\begin{abstract}
Academic libraries have in tandem, gradually assumed a superior role in a nation's development. Academic library policies and practices over the world have therefore advocated holistic research data management in a physical and virtual landscape. These dynamics have posed challenges and consequences for socio-economic development for academic libraries in Ghana. This study analyses and assesses research data management policies and practices in academic libraries in order to develop a strategic and comprehensive framework that depicts real time coordination among stakeholders for socio-economic development, thus setting a strong agenda for national development in Ghana. Using ethically professional research methods, this study adopted the purposive sampling techniques to select its sample size, scooped both quantitative and qualitative data from survey-based secondary data sources and modifies existing research data management theories and models to unravel and explain its findings. The Ghana Library Board (GLB), the Consortium of Academic and Research Libraries in Ghana (CARLIGH), and the Ghana Library Association (GLA) are key policy formulation agencies in Ghana's academic library industry with a goal of negotiating licensing agreements and play leadership roles to reinforce research data management. Poor level of collaboration between researchers and librarians, lack of research data management skill, lack of technological innovation and financial constraints are key challenges of academic libraries in Ghana. Surely, academic libraries in Ghana have exhibited potentials for revitalizing research data management in the areas of health, education, employment, land and housing, governance, water and sanitation, agriculture, energy, urbanization, youth and gender studies, and the environment. The recommended national research data management policy framework with an embedded enterprise wide research management information system will assure the world's academic library in-
\end{abstract}


dustry of an effective RDM strategy that drives global development, hone the expertise of academic libraries in Ghana and direct their research data management strategies.

\section{Subject Areas}

Information Science, Library, Intelligence and Philology

\section{Keywords}

Research Data, Research Data Management, Socio-Economic Development, Strategy, Academic Libraries

\section{Introduction}

As information management technologies have become the driving force behind global competitiveness, academic libraries have in tandem, gradually assumed a superior role in a nation's development. Notwithstanding the challenges of ascertaining the actual measure of economic and community enhancement [1], the efficient collection, use, access and dissemination of information by academic libraries influence the quality of long-term learning and consequences for national development [2]. In essence, academic library systems and infrastructure enables access to strategic and research information that informs competent planning policy formulation and implementation across all sectors of any economy [3]. In the same vein, academic library policies and practices over the world have advocated holistic research data management in a virtual landscape without neglecting its traditional roles of providing physical learning space, which revitalizes some social learning outcomes as evident in the Chinese University of Hong Kong [4]. Notable library policy and practices in contemporary global academic discourse communities include the creation of digital scholarship centers, librarian skill and professional development initiative implementation, collaborative partnership approach to research and development projects, and strategic leadership and innovation [5].

Research data management has undergone a rather tremendous paradigm shift in academic libraries thanks to the advancement in big data and cloud computing technologies. This new paradigm has emphasized data inventory preservation, standardized data organization, seamless data sharing and usage efficiencies and intellectual property protections, all geared towards satisfying the intensive data needs of users [6]. Although this may translate into a dwindling competitive positioning for academic libraries as they may be unable to respond and adapt to all of these trends [7], libraries play germane roles in the growth of several sectors of developing countries; human development, education, tourism, political stability, health and security [8] for national development. Key challenges with research data management in academic libraries have stressed equipment and personnel funding needs, myopic institutional support 
and the perceptual conflictions about data management scope and functions at the institutional level, which derives from capacity and policy imbalance [9]. In South Africa for instance, the unavailability of resources, infrastructure, and limited data management skills among library staff are major concerns [10].

These challenges coupled with their consequences for socio-economic development are major issues that academic libraries in Ghana have unsuccessfully tried over the years to deal with. Library and information systems promotion and development are not the priorities of development planners and policy makers mainly due to lack of funds and the misconception of the value of libraries, thus economic growth has virtually dwindled along with library and information services [11]. Successive governments have focused on infrastructural development in Ghana's academic library sector to the detriment of information technology, and even without an elaborate and comprehensive policy framework. Again, research projects in academic institutions are not informed by socio-economic development needs of the nation. Besides the uncoordinated research project planning and development, research data received at academic libraries are not effectively cataloged and conveniently disseminated according to sectoral policy development needs. These have generally stifled quality research information-powered socio-economic development in Ghana.

\subsection{Purpose and Originality/Value of the Study}

Whiles previous works have appreciated the role of academic libraries in national development, identified the main challenges faced, and have mainly recommended the need for physical and technological infrastructural development for academic libraries in Ghana, there still remains a research gap of unraveling the nitty gritty of the causal factors that underlie these challenges, and practically establishing how to raise funds to support infrastructural projects and the deployment of contemporary computer and information system technologies among all private and public stakeholders, towards managing research data and other traditional activities of academic libraries in order to propel growth in all sectors of Ghana's economy for national development. Filling this gap is the purpose of this research study.

\subsection{Scope of the Study and Definition of Keywords}

Having its handy objectives at heart, this study explores the broad policies and practices of research data management in the world's academic library systems, with emphasis on academic libraries in Ghana. The study also went on to uncover the factors that underlie the challenges of academic libraries in Ghana that it identified. This was necessary to understand the opportunities that academic libraries in Ghana can take advantage of and threats they can circumvent in order to ensure that the proposed research data management strategic framework is comprehensive and effective. In setting a strong agenda for national development in Ghana, the ramifications of research data management practices of aca- 
demic libraries on Ghana's socio-economic development activities is also assessed. This enlightened the path between research data management and national growth. Finally, the study innovatively creates a real time framework that ensures research data management practices are inextricably intertwined with national development, where all stakeholders will raise funds to support the effective conduct and convenient dissemination of research data to guide policy formulation and execution.

For the purposes of this study, the following words are key to grasping the varied perspectives of this paper; Research Data, Research Data Management, Strategy, Academic Library, and Socio-economic development. These should be understood s explained below. In the words of [12], research is an academic activity and a systematized effort to gain new knowledge. A research data set therefore constitutes a systematic partial representation of the subject being investigated [13] [14]. Research data encompass the recorded factual material commonly accepted in the scientific community as necessary to validate research findings, but excludes preliminary analysis, scientific paper drafts or laboratory samples, physical research plans, trade secrets such as commercial information, peer reviews, and medical and personal information [15]. Reference [16] identified four types of research data.

- Metadata or bibliographic data, which provides data about other data.

- Data underlying publications, data that validates scientific research publications.

- Curated data, which encapsulates data collections and structured databases, held on repositories.

- Raw data set, often held by institutions on hard drives.

Research data management was explained by authors in [17] to include a broad range of actors and activities with the roles and responsibility of enabling research data planning, assignment of metadata for discoverability and access, long term preservation and the introduction of new routines for governance and communication. Meanwhile, reference [18] emphasized that a research data management model should typify the six stages of data life cycle; including creating or collecting data, processing data from its raw state, analyzing the data to derive meaningful results, preserving the data, making the data accessible to others and reusing the data for future research projects.

Strategy provides an orderly route on which enables organization to operate seamlessly in its environment [19]. It typically emphasizes long-term planning horizons and business environment forecast [20]. According to [21], an academic library is a designated place, physical or digital, set aside to house scholarly research materials and other materials that support the academic, university or college community and curriculum.

Socio-economic development is the process of social and economic transformation that is derived from cultural and environmental factors, including improvement in people's lifestyles, social justice, education levels, income levels, 
skills development, employment, increased production, distribution, consumption of goods and services [22].

\subsection{Methodology and Ethical Considerations}

Depending on the phenomenon under study, it is critical for the appropriate research methods to be employed for the right type of research to ensure its quality outcome [23]. This study adopts an axiological research philosophy, since the author's values played a crucial role in the research perspectives; such as discussing the impact of research data management practices on the socioeconomic development of Ghana [24]. The study also applies both the inductive and deductive research approaches. With the deductive approach, theory is applied from the onset [25] whiles the inductive research works towards theory formulation and generalizing phenomenon [26]. Moreover, with its case study research strategy of analyzing the policies and practices of academic libraries in Ghana, it is also exploratory in purpose; seeking to unravel the underlying causes of the challenges of academic libraries in Ghana and its impact on national development.

The study population includes all academic libraries in the world and all stakeholders directly and indirectly involved in their research data management practices and policy formulation as well as government agencies and policymakers. However, the major public universities and technical universities libraries, their internal and external stakeholders were purposively sampled for analyzing and discussing the objectives of this study.

Although the study did not draw from first-hand information by the researchers, it draws significantly from empirical comparative deductions from a myriad of documentary secondary data and survey-based sources. The study also applies the research Triangulation method as described by [24] by using both qualitative and quantitative data from the relevant secondary sources. Relevant documents for reviewing literature included books, journals, magazine articles, and newspapers. Survey-based secondary data sources also included government publications and other policy information from government ministry websites.

Quantitative data were analyzed as presented in the secondary data sources, supporting them with frequencies and percentages of occurrences, pictures, graphs, and charts to enhance the discussions. The above was further explained with qualitative interpretations. Moreover, key research data management theoretical models were modified and reproduced as a strategic national development.

Regarding its ethical responsibilities, this study was sure to avoid the leakage of any personal or core business information of any selected member of its sample size, as well as downgrading their management operations. Instead, it focused objectively to collect, analyze, and publish its factual findings by all professionally ethical standards; without personal distortion and erroneous conclusion. 


\subsection{Significance of the Study}

With a coordinated enterprise-wide research data management system supported by an innovative fund management activity, the recommended comprehensive research data management policy framework will assure the world's academic library industry of an effective RDM strategy that drives global development. This by implication will also be true for Ghana's academic library industry and socioeconomic development.

Moreover, the study would hone the expertise of academic libraries in Ghana and direct their research data management strategies. Financial resource generalization from the proposed funding activity would also support required infrastructural development. Additionally, librarians in academic libraries would have job satisfaction fulfillment as the study would rekindle their research skills and expose them to modern library management information systems, whiles actively engaging them in executing the proposed strategic framework.

Finally, the study expands existing knowledge in library practices, research methodology and design, and research data management for national growth. It also guides scholars, researchers, academic institutions and government policymakers who wish to analyze the RDM practices of academic libraries in their countries and assess its impact on nation building.

\subsection{Research Objectives and Questions}

The overarching objective of this research is to analyze and assess research data management policies and practices in academic libraries in order to develop a strategic and comprehensive framework that depicts real time coordination among stakeholders for socio-economic development, thus setting a strong agenda for national development in Ghana.

Specifically, the study seeks to:

a) Assess research data management policies and practices of academic libraries in Ghana.

b) Identify key RDM challenges of academic libraries in Ghana and unravel their underlying causes.

c) Analyze the impact of RDM on the socio-economic development of Ghana.

d) Recommend strategic RDM practices in academic libraries for Ghana's socio-economic development.

Consequently, the study addressed the following questions;

a) What research data management policies and practices are evident in academic libraries in Ghana?

b) What research data management challenges do academic libraries in Ghana face? And what are their underlying causes?

c) How does research data management in academic libraries influence socio-economic development of Ghana?

d) What strategic research data management framework and practices in academic libraries would set Ghana on the path of national development? 


\subsection{Organization of the Study Sections}

The study is organized into eight broad sections. Section one generally introduces the trends in the academic library industry globally, its research data management problem with emphasis on Ghana, clarifies keywords and scope of the study, explains its significance and originality, considers some ethical values coupled with the appropriate methodology followed by the study objectives and research questions and highlights how the sections are organized. Section two provides a general background to the research by reviewing related literature on the academic library industry policy and practices; the challenges faced; the impact of research data management on socioeconomic development and research data management strategies. Section three discusses the research data management policies and practices of academic libraries in Ghana. Section four discusses the research data management challenges of academic libraries in Ghana. Section five discusses the impact of research data management on the socioeconomic development of Ghana. Section six offers strategic research data management recommendations for academic libraries in Ghana. Section eight draws a general conclusion highlighting limitations of the study and implications for future research.

\section{General Background to the Research}

Quite a great deal of research has been carried out in the library industry worldwide, which have indicated an edge in various institutions to develop technology-driven real time libraries and its associated human resource expertise, with limited emphasis on physical infrastructural development. To this end, therefore, several countries globally have transformed or are in the process of transforming policies and practices governing the management of their academic libraries especially. Existing literature has dealt extensively with analyzing general research data management trends in the library industry, challenges faced by academic libraries, ramifications of research data management on socio-economic development and recommendations for superior performance. However, it remains significantly quiet on the extent of central government's academic library policy formulation and implementation in developing countries, the underlying causes of challenges faced by academic libraries, and a rather cogent and practical framework that depicts a seamless relationship between strategic research data management practices in academic libraries and national development, particularly for developing countries.

In order to understand the various perspectives of the strategic positioning of academic library practices in national development, this section explores the current policy and practice trends in academic libraries worldwide, their challenges and causes, impacts of RDM on socio-economic development and some strategy recommendations as analyzed and presented in previous scholarly research works. 


\subsection{Academic Library Industry Policy and Practice Trends and Overview}

Policy and practices trending in the academic library industry have been rapid and consistent, similar to that of technological advancement and globalization. Meanwhile, developed countries relative to developing nations have greatly adapted and resisted failure amidst the new operational and strategic challenges that are implied. The authors in [27] conducted a survey of higher education libraries in Australia, Canada, Germany, Ireland, the Netherlands, New Zealand, and the United Kingdom. These countries stressed the need for effective RDM planning and training advocacy and policy development at the detriment of technical services such as data cataloging and curation. In a similar survey in the United States, Canadian and Australian college and research libraries, revealed the efforts of the National Data Service (NDS) and the Australian National Data Services (ANDS); syndicates of data management service providers, academic library institutions, publishers and computing firms, to enhance the practices of science, quality and ethical research [28] In India, the Council of Social Science Research (ICSSR) designed the ICSSR Data Service 13 to manage individual and institutional researcher project data that informs the nation's development policies [28].

Further emphasis on research data management policies and practices has also taken a significant shape in Africa as shown by [10]. Authors in [29] identified and discussed RDM awareness levels, leadership, policies and skills requirements in South African universities. For instance, an eResearch Centre has been established at the University of Cape Town whiles feasibility studies to validate the research data management projects were conducted at the University of South Africa [30]. According to the International Federation of Library Associations and Institutions (2015), the Zimbabwe Library Association implemented the Zimbabwe Agenda for Sustainable Socio Economic Transformation which aimed at synergizing research activities and national development.

More recent trends observed in the academic library industry were those published by the ACRL Research Planning and Review Committee (2018): research publishers have extended their services to include not only research database storing and dissemination but also analytics, discovery, and ethical quality research project management and workflow through partnership deals. Academic libraries are also dealing with fake news by engaging in information literacy promotions in order to render research data credible and accurate. In addition, the enrolment of research data acquisition, text mining and data science guidelines have also been on the fore; demand-driven acquisition (DDA) models rather than short term loan (STL) models are being applied.

\subsection{Academic Library Industry Challenges and Their Underlying Causes}

Reference [31] describes knowledge management (KM) as "a process of creating, storing, sharing, and re-using organizational knowledge (know-how) to improve 
its workforce". Gradually, the concept of knowledge management has become important in academic libraries has provided top-notch and ever-improving services library users across the world. In a bid to provide the best library management services, various challenges have been encountered especially in the academic library industry. It is evident that the world has rapidly moved towards information technology; hence customers of academic libraries showcase ever changing needs which must be met [32]. The various challenges in the industry have been elucidated in this section.

Globally, systems of education have changed radically, that is to say, teaching and learning are different from how they were about a decade or two ago. New systems like open and distance learning (ODL), virtual campus, and flipped classroom are gradually making the conventional way of visiting a library to look for books a thing of the past. The challenge here is that academic libraries are struggling to convert their entire knowledge collection into electronic resources [33]. There have also been changes in scholarly communications to encapsulate open access, institutional repository, and digital based scholarships and models of publication; these changes are so fast and academic libraries are being kept on their toes to bridge the gap between new and old methods of publishing intellectual works [34]. Authors in [32] identify that the challenges of academic libraries are intensified as a result of the need to unflinchingly train and educate staff and technology and infrastructural trauma. Reference [35]describes the emergence of IT as an "abundance that has replaced scarcity". Because thanks to 'search' which was once a key skill and specialty of librarians, is now a daily routine for most users, as they have developed confidence from the success rate of search history [36]. This transformation has rendered library professionals almost precipitated because library users do not really need their expertise to get information. They simply have to "Google it".

It turns out that, academic libraries even in advanced countries are confronted with budget and financial problems. University in the UK reported having budget issues with $36 \%$ experiencing a stagnant budget (no increase or decrease), 35\% having budget reductions and the remaining $29 \%$ experiencing minimal increases [37]. These researchers also found the situation in the US to be even worse as $44 \%$ of American universities had budget cuts, $22 \%$ had increased, and $42 \%$ had a steady budget. The Charleston survey reveals that in terms of staffing, US universities are most likely to cut staff salary and reduce working hours while UK universities will rather restructure.

Some of these challenges cut across all continents in the world. 21st century libraries in Africa are faced with challenges such as financial and budget constraints, insufficient infrastructure, deficient library access resources, and opposition of change among others [38]. These issues have made it an invariably huge challenge for African academic library industry to catch up with the neck-breaking take over by information technology. The academic library system and industry in Ghana which is the main setting of this paper is no exception to these challenges however, it appears more pressing. It was noted in [39] 
that a significant paradigm shift in the provision of library service in Ghana as a result of current technological advancement; hence the need for professional development to fit into the system. The problem, however, is that most private university libraries in Ghana have no professional development policies and hence zero budgetary allocation; this only results in lagging. In the same vein, the authors in [40] found that many library professionals in Ghana are educated and make use of social media platforms for personal and job-related purposes. However, their skills are not enough to use social media tools sequentially to improve library service and hence are resistant to change. According to [41], Ghanaian academic libraries have an inconvenient resolution and balance between traditional principles of public ethos and the need to pay for services.

Academic libraries in Ghana also have copyright challenges. In that, all departments of the University of Ghana rely on running photocopies of books from libraries as handouts for students to learn as a result of a huge number of students and few books. To Russell [42], one solo right of copyright holders is the right to reproduce or photocopy. This indicates a breach of copyright by most libraries across the country. The invention of digital copies makes it almost impossible to control those who breach copyright.

\subsection{Impact of Research Data Management in Academic Libraries on Socio-Economic Development}

Socioeconomic development can generally be described as creating wealth through jobs to improve quality of life. The importance of research data management is very well highlighted throughout literature over the years [9]. Similarly, authors in [6] opined that researchers have the need to manage data due to computational and data-intensive research which has as a matter of convention become mandatory for scholars [43]. Unfortunately, lots of scholarly researchers do not have the required skills [44] and face challenges of research data management ranging from back up, storage to integrity issues. This is in tandem with the views of the authors in [45] who also found that the needs and concerns of librarians about skills learning are akin in New Zealand, UK, Australia, and Ireland. The following section highlights how research data management in academic libraries can impact socioeconomic development.

Valantin [46] notices the inseparability of information (processed data) and the ability of any government to make concrete policy decisions. The ability to rightly interpret culturally and economically relevant data requires topnotch data management skills which brings the onus back to academic libraries. The academic libraries provide access to all aspects of data to enable the economic management team to make the best decision. This is however impossible without development of information and communication systems. Accurate research data management enhances human capital which in turn promotes national development [3].

With advanced education comes the emergence of high quality human resource base for a country and this has always been the focus of academic libraries in practicing research data management [47]. Besides, people need to have 
access to information from academic libraries to be well equipped to give their opinions on political, economic, and social developmental issues. This is made easier if proper research data management is practiced by academic libraries.

In Ghana, research into agriculture has helped in many ways promote socioeconomic development as agriculture has been the backbone of the economy for long. Academic libraries provide the needed information to the ministry of food and agriculture to make informed policy decisions and in the past has kept Ghana on course in achieving the sustainable development goals. Libraries have also helped disseminate information about health especially in rural Ghana which has improved life expectancy, adolescent reproductive health, and overall health consciousness of the populace [48]. Even though most rural people are ignorant of the role the library plays in disseminating health information, it has helped eradicate some basic health challenges to a reasonable extent.

\subsection{Strategies for Managing Research Data in Academic Libraries}

Proposed research data management strategies in previous works have been more operational than tactical and strategic. They emphasize the need for the incorporation of information technology systems and infrastructure to enable academic libraries to cope with existing standards for data quality and use. Reference [49]identified storage, security, quality, compliance, preservation, and sharing as key driving forces of research data management strategies, with country specific factors including governance, resourcing, and skills, influencing ongoing developments. However, stakeholders in research data development; such as research firms, library institutions, and computer technology firms, have suffered in coordination and uncertainty. This coordination was depicted in their proposed model (Figure 1).

Another revealing survey conducted by authors in [7] indicated that collections development and management occupied a critical place in the strategic research data management plans of academic libraries, with appropriate physical space facility ergonomics and development, and information literacy in library instruction following in that other of relevance. Moreover, whiles it was confirmed that academic libraries have magnified their scope and service levels in order to explore the opportunities that open access repositories; such as facilitating data access, keeping and sharing, present to the industry, research data service policy and infrastructural development is rather inadequate or perhaps negligible [50].

With empirical evidence from the Cornell University, Perdue University, Rice University and the University of Oregon, author in [51] discussed practical research data management strategies for information professionals in academic libraries as involving the convenience of preserving, validating, reusing, sharing and protecting data, the development of data management plans with assistance in scholarly communication and open access publication, developing new fund requirements for data management funds, the organization of large data volumes to facilitate effective assignment to users, the development of policy and 


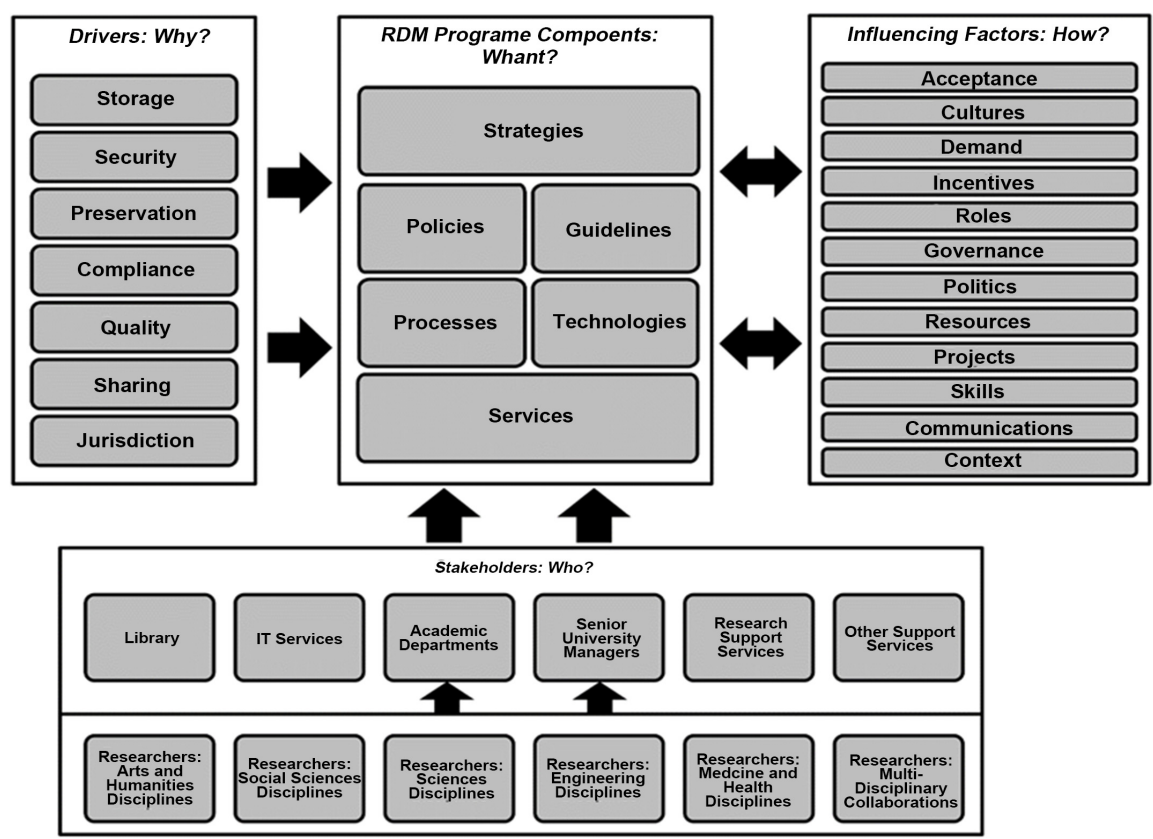

Figure 1. Show the Research Data Management processes and stakeholder relationships. Source: Pinfield, et al. (2014) [49].

institutional framework such as the distributed data curation center and services, and the management of project data in archives and repositories such as copyright and data sharing [51].

Reference [52] fine-tuned the data curation life cycle model by discussing the various stages of the model and its application to research data management. In a nutshell, the model explains the planned scrutiny and manipulation of data including how to maintain, preserve and add or extract value from research data to achieve a proposed trend. The model stages encapsulate first, the planning for data creation, capturing, and storage, and ends with a predicted transformation in a predicted order. Other intermittent actions may also include data disposal, reappraisal, and migration (Figure 2). These may be necessary to address changes in government legislations and confidentiality issues [52].

Moreover, the adoption of the Data Service Program by Indiana University as part of their strategic plan in 2014, which was mainly influenced by the university's library, cannot be overemphasized. The library's strategic perspectives aimed at facilitating and increasing the dissemination of research and scholarship; support new metrics to assess research impact at all levels and facilitate data re-use, evaluation and archiving [53]. The program generally aimed at creating research data management awareness, streamlining data integrity issues, enhancing institutional resources, supporting data management, and honing the data management skills of researchers.

\subsection{Summary}

By dint of an appreciable commitment of human and financial resources, research institutions and academic libraries worldwide have lived up to the developing 


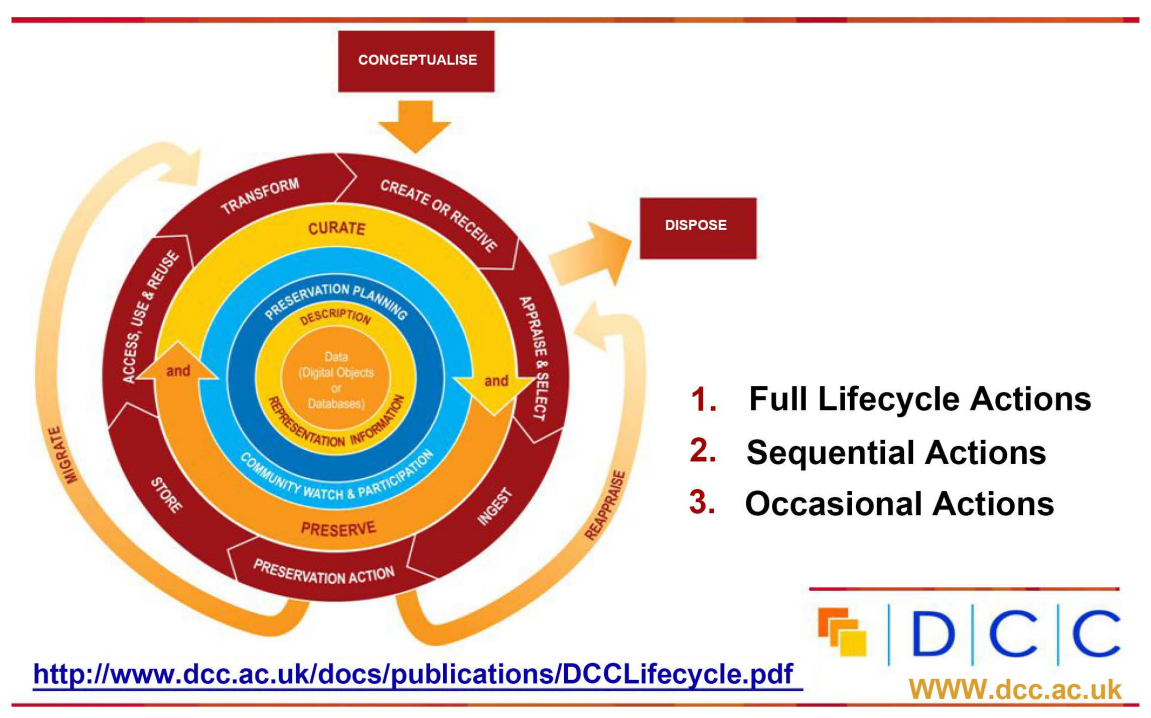

Figure 2. Show the DCC Curation lifecycle model.

trends in research data management, albeit it cannot be paralleled with the current scope and rate of information requirements and use, such as those in developing countries. Critical challenges are the lack of technological expertise, finance, coordination among stakeholders and infrastructural facilities. These have been caused by the lack of comprehensive policies, limited partnership programs, inadequate funding sources, and low public sensitization programs. Academic libraries worldwide have contributed immensely to projects and programmes developed in various sectors of their economies, providing research and community development consultancy services. However, these practices are intermittent projects instead of a development convention. Consequently, most research data management strategies proposed have omitted the practical connection with national development. This study, therefore, designs a framework that imbibes a path towards national development.

\section{Research Data Management Policies and Practices of Academic Libraries in Ghana}

Library institutional policies and practices in Ghana have been characterized by piece-meal governing standards and norms that only commensurate with the organizational strategy of the institution involved. Meanwhile, the Ghana Library Board (GLB) was formed as far back as 1946 but was not established as an Act of parliament (Act 372) until 1970 to perform functions including establishing, equipping, staffing, training, managing and maintaining public libraries in Ghana [54]. Although the GLB does not have an information and communication technology policy, its key responsibilities include ICT services, training staff and sharing relevant information to rural development agencies through public libraries [55]. In 1989, the Central Reference and Research Library of the Council for Scientific and Industrial Research (CSIR) established the Ghana National Scientific and Technological Information Network (GHASTINET) to coordinate 
and align scientific research worldwide to the development needs of Ghana [55]. Moreover, the Database of African Thesis and Dissertations (DATAD) project was initiated by the Association of African Universities (AAU) in 2000 to store and disseminate theses and dissertations of African Universities globally using CD-ROMs and the internet. Furthermore, the Consortium of Academic and Research Libraries in Ghana (CARLIGH) was also configured in 2004 to enable access to electronic journal databases, negotiating licensing agreements and promoting cooperation and networking among academic and research libraries in the country [56]. In addition, the Ghana Library Association (GLA) continually organized workshops to train library personnel, especially on modern technologies for information delivery.

Sharma in [55] identified four types of libraries in Ghana namely; school, special, public and academic. At the University of Ghana, research data management practices are evident notwithstanding the absence of RDM policy; collaborative research, data analysis and computational science support, storage facilities with high speed connectivity, an institutional repository (UG Space), a private cloud facility (HP Cloud Matrix), network and security infrastructure and an institutional Google Drive Platform [57].

In addition, there was evidence of a performance measurement policy targeted at economic development: in a survey of 5 public university Libraries in Ghana, three of the libraries were found to measure the performance of their libraries [58]. Similarly, the researchers in [59] studied the influence of technological advancement on the implementation of digital library systems in three public universities in Ghana; University of Ghana, Kwame Nkrumah University of Science and Technology and the University of Cape Coast. Systems deployed include online database institutional repositories, online public access catalogues (OPAC) and websites, with a somewhat access restriction to the OPAC.

With a comprehensive collection development policy and a member of the CARLIGH, the University of Development Studies library has been able to improve its books collection process and subscription to several international and Ghanaian research journals; develop its information literacy support systems, which ensures quality research, teaching, learning and utilization of research data; develop its institutional repositories for efficient dissemination of research data; automate its library systems; establish an electronic unit support and played leadership roles in GLA programmes in the northern region of Ghana [60].

An exploratory research conducted in [61] revealed that the routine activities of the polytechnic university libraries in Ghana that reinforced research data management included research author aid and services, institutional database repository development, information literacy, and digitization. These translated into academic integrity, competitive positioning for grants, research standardization, transparency and accountability and the building of honorable reputation. 


\section{Research Data Management Challenges of Academic Libraries in Ghana and Their Causes}

Excellent data management is a key predictor of data and research quality; it encapsulates handling, organizing, documenting, and enhancing data [62]. The life-cycle of research data management involves planning, creating data, processing data, analyzing data, preserving data, giving access to data and re-using data [63]. Academic libraries refer to all libraries that are focused on student users in various campuses. In Ghana, academic libraries are the libraries in colleges of education, universities, polytechnics, and all other tertiary institutions. A general challenge experienced by all academic libraries across the world is the evident change of context towards information technology. Even though these developments are important for libraries, it must be noted that people-oriented skills which are a basis for quality research data management cannot be overlooked [41]. The authors in [64] noted that academic libraries in Ghana have highly professional staff, good infrastructure, and good services. However, in the area of research data management which must be explored and their causes pinpointed.

The authors in [65] acknowledged that research data management is a major challenge to academic libraries in Ghana because many researchers now write, store, and share large volumes of research data in digital forms which makes it inaccessible for libraries. Steps of handling this challenge have however been taken and are far advanced as some universities have experienced some success in implementing some policies. Staff training, career development plans, and educational campaigns are also being held.

A poor level of collaboration between researchers and librarians as a result of the two using different vocabulary also hinders RDM [18]. To elucidate further, researchers speak the language of research and Librarians speak library language. The lack of guidance on good research data management practices, technology obsolesce and fragility, lack of human and financial resource were identified as serious hindrances to research data management [66]. These challenges are applicable to the Ghanaian context too as it is confirmed by [57] that staff of the University of Ghana library demonstrated an idea of what RDM is and its need but did not know exactly what it is.

The author in [67] also identifies economic recessions (which creates restriction mainly to open access research), information explosion, and technological innovation as the key issues that have led to a change in traditional academic library systems and a difficulty in research data management in Ghana.

The above analysis shows a clear background of the current state of research data management in Ghana, the key roles of Ghanaian academic libraries and the challenges they face in managing research data. It is evident from the literature that financial constraints tend to be the basis of all other challenges; in that, more budgetary allocation will make training and professional development programs easy to run. Hence, an improvement in RDM service in Ghana. 


\section{Impact of Research Data Management in Academic Libraries on Ghana's Socio-Economic Development}

The spatio-temporal evidence of the incredible role of academic libraries in a nation's development is rife in the literature. Libraries have over the centuries, been repositories of information and knowledge which provide the basis for socio-economic, political and cultural development [68]. Although academic libraries in Ghana have outlived their socio-economic development usefulness, the potentials for revitalizing research data management to guide programs and projects in Ghana are not far-fetched.

According to the Institute for Statistical, Social and Economic Research (ISSER), its Social Division conducts systematic qualitative and quantitative research project compilations dubbed Ghana Social Development Outlook (GSDO) that span the social and economic sectors of Ghana including health, education, employment, land and housing, governance, water and sanitation, agriculture, energy, urbanization, youth and gender studies, and the environment, and envisions to examine the state of social development in Ghana in order to recommend development policies. In addition to conducting Consumer Satisfaction Survey for the National Communications Authority, the Measuring Learning and Evaluation (MLE) Unit of ISSER supported major projects in Ghana including; an Impact Evaluation of Inoculants Usage on Farmer Yields and Farm Incomes from 2014 to 2017, Endline Survey of the Impact Evaluation of the Home-Grown School Feeding (HGSF) Programme, Training Workshop for the Ministry of Trade and Industry (MOTI), Climate Change Budget and Financial Tracking Tools (ISSER, 2016).

Additionally, the Chattered Institute of Bankers Ghana (2019) confirmed that there were plans to automate their libraries to enable the local and international communities to access education and research materials on-line and as well enjoy an inter-library loan facility with affiliated institutions. These materials explore disciplines including banking, finance, insurance, accountancy, economics, investment, law, management, and taxation. For instance, the Kumasi Library and the Accra Library functions as an educational information hub to provide banking and finance related solutions to the northern sector bracket; Ashanti, Brong Ahafo, Northern, Upper West, and Upper East Regions (Chattered Institute of Bankers Ghana, 2019).

Furthermore, the Ghana Library Authority's 'Technology for Maternal Health' service in northern Ghana, adequately positions itself to equip health-workers and pregnant women with requisite information in the quest to reduce maternal mortality and the overall cost of healthcare delivery [69]. More so, community libraries and information vans in Ghana are tasked to meet the information needs of the local people, agricultural librarians and agricultural extension workers repackage and disseminate information in the language medium that they can easily absorb [56]. 


\section{Strategic Research Data Management Recommendations for Academic Libraries in Ghana}

Research data management in academic libraries can be regarded as strategic if it transcends the adoption and application of modern advanced technologies to conduct quality research projects, store and disseminate data and information derived; as espoused in previous works, to include an inter and intra connected real time system of academic libraries and all private and public agencies that have direct and indirect stake in national development. A national development policy is worth not implementing if its planning process does not feed on quality research data. Conversely, research data in academic libraries should also be managed in a way that conveniently informs national development. As explored in previous sections, development policies in Ghana are mostly not informed by in-depth research and strategic plans, thus, development processes are back and forth. Although significant efforts are being made by academic libraries toward improving research data management in order to support Ghana's development projects, an innovative fund generation and management activity are lacking. This section recommends a national research data management policy framework with an embedded enterprise wide research management information system (Figure 3), that should do the trick when executed. These have been discussed below;

Install an enterprise information system technology. First, there is a need to interconnect all stakeholders ranging from public agencies, business organizations, funding agencies, and academic libraries. Academic libraries should share a web based three level enterprise information system; made of an Executive Information System (EIS), Management Information System (MIS) and Transaction Processing System (TPS). Each stakeholder must have its management information system unit that is interoperable with that of other stakeholders, and via which they can request or receive research services.

Student Research Projects should be derived from national development policy needs. To cope with the current trends of academic library practices of research and development, various universities should collaborate with government and private agencies through the installed enterprise information system to compile their project and programs development plans, challenges and information requirements in order to create research project topics, execute them according to quality ethical standards and present solution based implementations recommendations to the institutions involved. This means that students would bring to bear their research skills and work on research projects that would create a profession for them whiles aiding to undertake well informed development projects for Ghana's development.

All sector ministries should include academic libraries into policy formulation and implementation. It is also conversely important that the ministries and authorities of various sectors of Ghana should forward their annual action plans to academic libraries in Ghana as a matter of requirement, to enable the active 


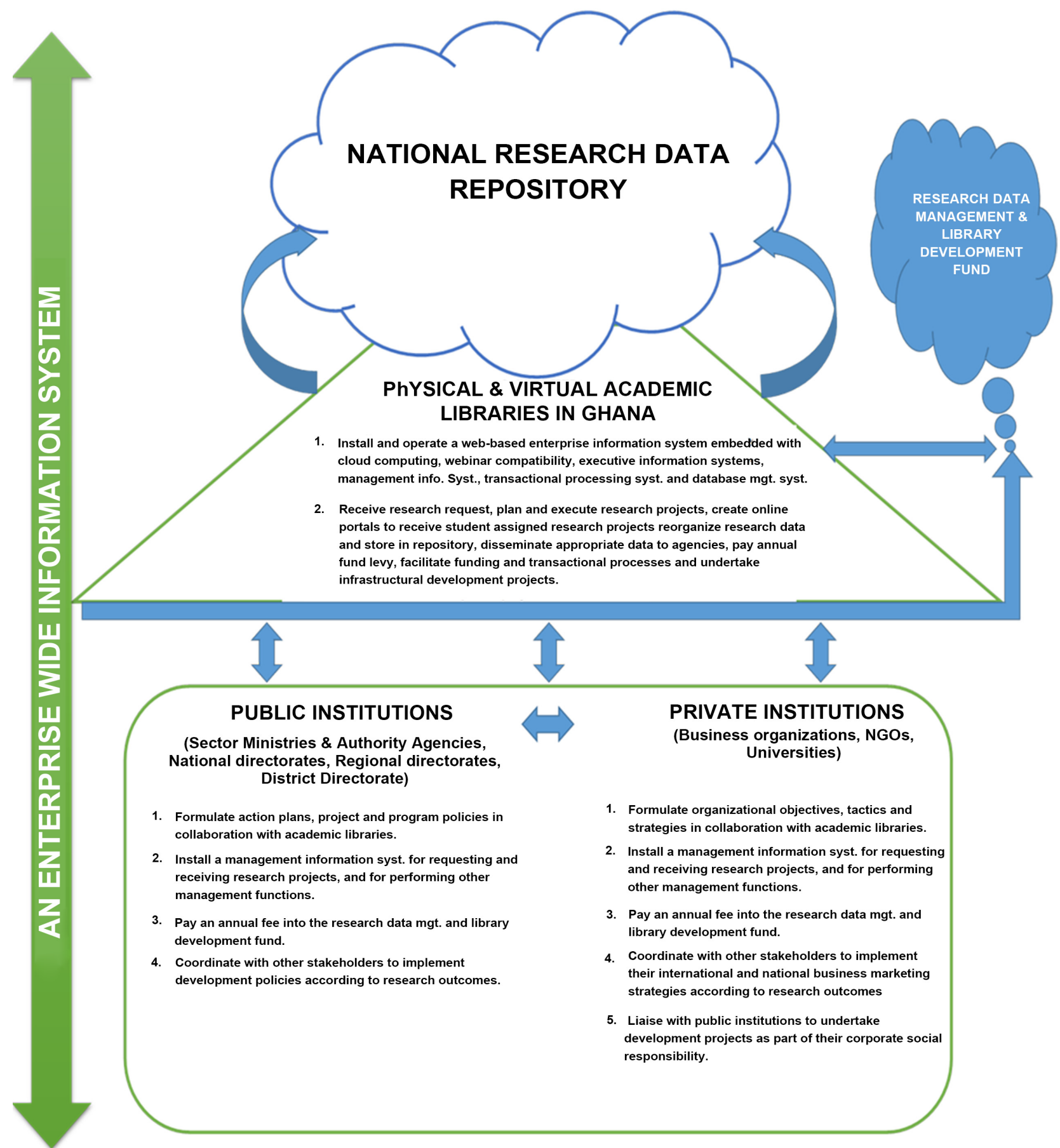

Source: Researcher 2019

Figure 3. Show a national research data management policy framework for academic libraries in Ghana.

involvement of academic libraries in planning the development of the nation. This does not exclude private businesses that operate in various industry sectors. There is the need for the research and development units of these organizations to collaborate with academic libraries to discuss their challenges develop new products, conduct market markets research, exchange data and design competitive strategies for international business towards ensuring economic growth for 
Ghana.

Build innovative fund generations and management account. The above recommendations may not be realized fully without funding opportunities. It is therefore critical that a fund should be created backed by an act of parliament to involve all stakeholders to pay an annual research data management and academic library development fee in addition to government budgetary allocations. This would be done in collaboration with a selected bank as the fund manager. These funds would be channeled to expanding research project capacities and academic library infrastructure as budgeted by the appropriate authority in collaboration all stakeholders.

Formulate a national research data management policy. Finally, the enforcement of these recommendations is also very crucial to ensure that academic libraries serve their purpose of national development. To this end, a national research data management policy should be formulated and backed by law to prescribe and coordinate the activities of each identified stakeholder and ensure compliance.

\section{General Conclusion}

The discussions in this paper show that research is undoubtedly the core of policy planning and development projects. Thus, the quality management of research data has become a necessity for national development. With the mantle now falling on academic libraries to spearhead research data management towards creating, storing and disseminating the right research information to policy makers and business operators to guide national growth and development, it is vital to adopt a holistic approach that ensures real time coordination among stakeholder. This approach is sure to minimize the burden of inadequate financial and physical infrastructural resource, as well as a means of enhancing the research management technological skills of personnel involved. It must be reemphasized finally that this paper presents a one-stop shop for remodeling Ghana's academic library and research data management systems to achieve significant national development.

\subsection{Limitations of the Study}

The study suffered few constraints. First, it used a relatively small secondary data sample size relative to the given population for its analysis. This may obscure the unraveling of the true nature of the challenges facing academic libraries in Ghana and its impact on socioeconomic development. Secondly, given the copyright issues that confronted most academic libraries and universities in Ghana, they are reluctant to disclose some confidential data, which would have widened the scope of generalizing the study result analysis, discussions and conclusions.

\subsection{Implications for Future Research}

This study focused on analyzing and assessing research data management poli- 
cies and practices in academic libraries in order to develop a strategic and comprehensive framework that depicts real time coordination among stakeholders for socio-economic development, In order to set a strong agenda for national development in Ghana.

Future research studies should, however, conduct feasibility studies on how to implement the proposed national research data management policy for academic libraries in Ghana, associated challenges and the way forward. Again, future works should be directed at programming and developing the web-based software engineering systems required to run the operations of the proposed framework. Finally, this study should also be replicated on international level to guide international business and trade policies.

\section{Acknowledgements}

This work was supported by National Social Science Foundation of China "Study of Research Data Governance under the Concept of Open Science" (No: 17BTQ025). The authors would like to thank anonymous reviewers for their great comments that helped to improve this paper.

\section{Conflicts of Interest}

The authors declare no conflicts of interest regarding the publication of this paper.

\section{References}

[1] Indiana Business Research Center (2007) The Economic Impact of Libraries in Indiana. http://www.ibrc.Indiana.edu

[2] Thanuskodi, S. (2013) Challenges of Academic Library Management in Developing Countries. IGI Global, Hershey. https://doi.org/10.4018/978-1-4666-4070-2

[3] Sobalaje, A. and Ogunmodede, T. (2015) Roles of Academic Library in the National and Economic Development of Nigeria. Greener Journal of Social Sciences, 5, 36-41. https://doi.org/10.15580/GJSS.2015.2.281114401

[4] Wales, T. (2014) Business School Libraries' Futures?

[5] Kosavic, A. (2016) Developing Digital Scholarship: Emerging Practices in Academic Libraries. ALA Neal Schuman, Chicago, 184 p. https://doi.org/10.5860/crl.78.7.1004

[6] Tenopir, C., Birch, B. and Allard, S. (2012) Academic Libraries and Research Data Services. Current Practices and Plans for the Future. Association of College and Research Libraries, Chicago.

[7] Saunders, L. (2015) Academic Libraries' Strategic Plans: Top Trends and Under-Recognized Areas. The Journal of Academic Librarianship, 41, 285-291. https://doi.org/10.1016/j.acalib.2015.03.011

[8] Agbo, A.D. and Onyekweodiri, N.E. (2014) Libraries Are Dynamic Tools for National Development. Chinese Librarianship: An International Electronic Journal, 38, 29-35.

[9] Yoon, A. and Schultz, T. (2017) Research Data Management Services in Academic Libraries in the US: A Content Analysis of Libraries' Websites. College \& Research Libraries, 78, 920-933. https://doi.org/10.5860/crl.78.7.920 
[10] Chiware, E. and Mathe, Z. (2015) Academic Libraries' Role in Research Data Management Services: A South African Perspective. South African Journal of Libraries and Information Science, 81, 1-10. https://doi.org/10.7553/81-2-1563

[11] Alemna, A.A. (1989) Libraries and the Economic Development of Ghana. Aslib Proceedings, 41, 119-125. https://doi.org/10.1108/eb051131

[12] Bhattacharyya, D.K. (2006) Research Methodology Excel Books.

[13] OECD (2007) Annual Report 2007.

[14] Miller, T., et al. (2012) Ethics in Qualitative Research. 2nd Edition, SAGE Publications Ltd., London.

[15] Regulations, C.F. (2000) Title 21. Chapter I (Revised).

[16] Kruse, F. and Thestrup, J.B. (2017) Research Data Management-A European Perspective. Walter de Gruyter GmbH \& Co KG, Berlin.

[17] Pryor, G., Jones, S. and Whyte, A. (2013) Delivering Research Data Management Services: Fundamentals of Good Practice. Facet Publishing, Cambridge. https://doi.org/10.29085/9781783300242

[18] Surkis, A. and Read, K. (2015) Research Data Management. Journal of the Medical Library Association, 103, 154. https://doi.org/10.3163/1536-5050.103.3.011

[19] Murugappan, P. (2014) Cost Reduction Strategies for the Manufacturing Sector with Application for Microsoft Excel. Blue Micro Solution, Kuala Lumpur.

[20] Sehgal, V. (2010) Supply Chain as Strategic Asset: The Key to Reaching Business Goals 22. John Wiley \& Sons, Hoboken. https://doi.org/10.1002/9781118269176

[21] Crummett, C. and Perrault, A. (2008) The Use of CMC Technologies in Academic Libraries. In: Handbook of Research on Computer Mediated Communication, IGI Global, Hershey, 705-719. https://doi.org/10.4018/978-1-59904-863-5.ch050

[22] Saurabh, S., Anshuman, B. and Ruchi, S. (2016) International Perspectives on Socio-Economic Development in the Era of Globalization. IGI Global, Hershey.

[23] Hair Jr., J.F., Wolfinbarger, M., Money, A.H., Samouel, P. and Page, M.J. (2015) Essentials of Business Research Methods. Routledge, Abingdon-on-Thames. https://doi.org/10.4324/9781315704562

[24] Saunders, M., Lewis, P. and Thornhill, A. (2009) Research Methods for Business Students. Financial Times/Prentice Hall, Harlow.

[25] Hyde, K.F. (2000) Recognising Deductive Processes in Qualitative Research. Qualitative Market Research: An International Journal, 3, 82-90. https://doi.org/10.1108/13522750010322089

[26] Sondhi, N. and Wilson, J. (2010) Essentials of Business Research-A Guide to Doing Your Research Project. SAGE Publications, New Delhi. https://doi.org/10.1177/097215091101200211

[27] Cox, A.M., Kennan, M.A., Lyon, L. and Pinfield, S. (2017) Developments in Research Data Management in Academic Libraries: Towards an Understanding of Research Data Service Maturity. Journal of the Association for Information Science and Technology, 68, 2182-2200. https://doi.org/10.1002/asi.23781

[28] Tripathi, M., Shukla, A. and Sonkar, S.K. (2017) Research Data Management Practices in University Libraries: A Study. DESIDOC Journal of Library \& Information Technology, 37, 417-424. https://doi.org/10.14429/djlit.37.6.11336

[29] Kahn, M., Higgs, R., Davidson, J. and Jones, S. (2014) Research Data Management in South Africa: How We Shape up. Australian Academic \& Research Libraries, 45, 296-308. https://doi.org/10.1080/00048623.2014.951910 
[30] Macanda, M., Rammutloa, M. and Bezuidenhout, R. (2014) Research Data Management at Unisa. http://uir.unisa.ac.za/handle/10500/13907

[31] Guru, B., Gopalaswamy, M., Arun, J. and Padmamma, S. (2009) Academic Library Management in India Challenges and Opportunities.

[32] Chutia, U.P. (2015) Academic Libraries of 21st Century: Challenges for Librarian. International Peer Reviewed Bilingual E-Journal of Library and Information Science, 2, 255-271.

[33] Tikekar, A. (2009) Towards 21st Century Academic Libraries and Librarianship. Vision and Roles of the Future Academic Libraries, Delhi University Library System, University of Delhi (North Campus), 5-8 October 2009, 45-50.

[34] Murphy, K. (2012) The Challenges Facing Academic Libraries in the 21st Century. Melville House Books, Brooklyn.

[35] MacColl, J. (2010) Academic Libraries and the Challenge of Abundance: The Impact of the Explosion of Retrievable Information on Universities. From Information to Knowledge; from Knowledge to Wisdom.

[36] Hanson, C., Hessel, H., Barneson, J., Boudewyns, D.K.U., Fransen, J., Friedman-Shedlov, L., et al. (2009) Discoverability Phase 1 Final Report.

[37] Nicholas, D., Rowlands, I., Jubb, M. and Jamali, H.R. (2010) The Impact of the Economic Downturn on Libraries: With Special Reference to University Libraries. The Journal of Academic Librarianship, 36, 376-382. https://doi.org/10.1016/j.acalib.2010.06.001

[38] Jain, P. and Akakandelwa, A. (2016) Challenges of Twenty-First Century Academic Libraries in Africa. African Journal of Library, Archives \& Information Science, 26, 147.

[39] Dzandza, P.E. and Akussah, H. (2018) Professional Development in Private University Libraries in Ghana. Library Management, 39, 488-502.

https://doi.org/10.1108/LM-06-2017-0055

[40] Ahenkorah-Marfo, M. and Akussah, H. (2016) Changing the Face of Reference and User Services: Adoption of Social Media in Top Ghanaian Academic Libraries. Reference Services Review, 44, 219-236. https://doi.org/10.1108/RSR-01-2016-0001

[41] Badu, E.E. (2004) Academic Library Development in Ghana: Top Managers' Perspectives. African Journal of Library, Archives and Information Science, 14, 93-107.

[42] Russell, C. (2001) Libraries in Today's Digital Age: The Copyright Controversy: ERIC Clearinghouse on Information \& Technology. Syracuse University, Syracuse.

[43] Holdren, J.P. (2013) Memorandum for the Heads of Executive Departments and Agencies: Increasing Access to the Results of Federally Funded Scientific Research.

[44] McLure, M., Level, A.V., Cranston, C.L., Oehlerts, B. and Culbertson, M. (2014) Data Curation: A Study of Researcher Practices and Needs. Portal: Libraries and the Academy, 14, 139-164. https://doi.org/10.1353/pla.2014.0009

[45] Kennan, M.A. and Markauskaite, L. (2015) Research Data Management Practices: A Snapshot in Time. International Journal of Digital Curation, 10, 69-95.

https://doi.org/10.2218/ijdc.v10i2.329

[46] Valantin, R. (1996) Global Program Initiative: Information Policy Research. Information Technology for Development, 7, 95-103. https://doi.org/10.1080/02681102.1996.9525273

[47] Akintunde, S.A. (2004) Libraries as Tools for ICT Development.

[48] Agyei, D.D., Adu, S.M., Yeboah, E.A. and Tachie-Donkor, G. (2018) Establishing 
the Knowledge of Health Information among Adolescent Postpartum Mothers in Rural Communities in the Denkyembour District, Ghana. Advances in Research, 14, 1-8. https://doi.org/10.9734/AIR/2018/39939

[49] Pinfield, S., Cox, A.M. and Smith, J. (2014) Research Data Management and Libraries: Relationships, Activities, Drivers and Influences. PLoS ONE, 9, e114734. https://doi.org/10.1371/journal.pone.0114734

[50] Yu, H.H. (2017) The Role of Academic Libraries in Research Data Service (RDS) Provision: Opportunities and Challenges. The Electronic Library, 35, 783-797. https://doi.org/10.1108/EL-10-2016-0233

[51] Ray, J.M. (2014) Research Data Management: Practical Strategies for Information Professionals. Purdue University Press, West Lafayette.

[52] Pryor, G. (2012) Managing Research Data. Facet Publishing, Cambridge. https://doi.org/10.29085/9781856048910

[53] Hoffman, S. (2016) Dynamic Research Support in Academic Libraries. Facet Publishing, Cambridge. https://doi.org/10.29085/9781783301225

[54] Engman, N., Kavi, R., Obeng-Koranteng, G. and Bugyei, K. (2016) An Assessment of the Ghana Library Authority In-Service Training for Junior Library Assistants.

[55] Sharma, R.N. (2012) Libraries in the Early 21st Century, Volume 2: An International Perspective. Walter de Gruyter GmbH \& Co KG, Berlin. https://doi.org/10.1515/9783110292855

[56] Lamptey, R.B., Sambo, I.A. and Hassan, A.A. (2017) Disseminating and Promoting Agriculture Information through Library and Information Services in Ghana. Qualitative and Quantitative Methods in Libraries, 5, 901-907.

[57] Avuglah, B.K. (2016) Developing an Implementation Plan for Research Data Management (RDM) at the University of Ghana. University of Pretoria, Pretoria.

[58] Badu, E. (2009) Performance Measurement in Academic Libraries in Ghana. Ghana Library Journal, 21. https://doi.org/10.4314/glj.v21i1-2.69494

[59] Dadzie, P.S. and van der Walt, T. (2015) Planning for Digitization of University Libraries in Ghana: Challenges and Prospects. Library Philosophy and Practice, 1, 1206.

[60] Thompson, E., Amuda, J. and Akeriwe, M. (2015) Twenty Years of Academic Librarianship in Ghana: The University for Development Studies Library's Experience. UDS International Journal of Development, 1, 59-70.

[61] Barfi, F.K. (2017) Awareness of Academic Research Ethics among Senior Polytechnic Librarians in Ghana. University of Ghana, Ghana.

[62] Corrall, S., Kennan, M.A. and Afzal, W. (2013) Bibliometrics and Research Data Management Services: Emerging Trends in Library Support for Research. Library Trends, 61, 636-674. https://doi.org/10.1353/lib.2013.0005

[63] Benneh, E.A., Ayiah, E.M. and Kantanka, E.S. (2017) Institutionalizing Research Data Management Practices in Academic Institutions in Ghana: The Role of the Library. STU International Journal of Technology, 1, 1-17.

[64] Lamptey, R. and Agyen-Gyasi, K. (2010) Vision of the Future Academic Libraries in Ghana.

[65] Abankwa, F. and Yuan, R. (2019) The Role of Academic Libraries in Research Data Management: A Case in Ghanaian University Libraries. Open Access Library Journal, 6, e5286. https://doi.org/10.4236/oalib.1105286

[66] Harvey, D.R. (2010) Digital Curation: A How-to-Do-It Manual. Neal-Schuman 
Publishers, Chicago.

[67] Asamoah-Hassan, H.R. (1998) Mission of the Academic Library in Ghana in the 21st Century.

[68] Alemna, A.A. (2000) Libraries, Information and Society. Ghana University Press, Ghana.

[69] Fairbairn, J. and Lipeikaite, U. (2014) Small Services Big Impact: Public Libraries' Contribution to Urban and Rural Development. 